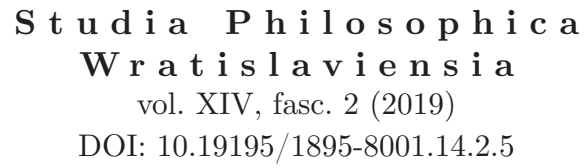

IWO GRECZKO

ORCID: 0000-0002-4174-7034

Uniwersytet Adama Mickiewicza w Poznaniu

\title{
Autentyczność i teatralność. Andrzeja Falkiewicza koncepcja człowieka teatralnego w kontekście krytyki radykalizmu Helmutha Plessnera
}

\begin{abstract}
Authenticity and theatricality: Andrzej Falkiewicz's model of homo theatralis in the context of Helmuth Plessner's criticism of radicalism
\end{abstract}

Abstract: The aim of this work is to confront Andrzej Falkiewicz's model of "homo theatralis" and - to a lesser degree -being-as-metaphor" with Helmuth Plessner's criticism of radicalism. In the first step the author shows generally the problem of "self" and moral sources of identity. In the second step the author analyzes the concept of "homo theatralis" ("theater man") and "being-as-metaphor" by the Polish writer, critic, and philosopher Andrzej Falkiewicz-Leszek Nowak's cooperator. In the third step the author is trying to connect Falkiewicz's ideas with Helmuth Plessner's model of radicalism (connected with his concept of commonwealth and society and difference between them). Then the author answers the question of the possibility of freedom in building our individual moral horizon.

Keywords: social science, authenticity, theatricality, ceremonial, homo theatralis

My gramy wielki spektakl w kosmosie. I tylko dzięki temu spektaklowi nadajemy ,sensy" rzeczywistości, która jest „bezsensowna”. Czy można by lepiej zagrać ten spektakl? ${ }^{1}$

Andrzej Falkiewicz

${ }^{1}$ A. Falkiewicz, Teatr Społeczeństwo, Wrocław 1980, s. 230. 


\section{Wstęp}

Dla antropologii filozoficznej ważnym pytaniem jest to o możliwość bycia ,autentycznym". Samo to pojęcie jest spuścizną romantyzmu: w jego myśl jednostki odkrywają prawdę o sobie we własnym wnętrzu. To założenie podał krytyce między innymi Charles Taylor ${ }^{2}$, a wcześniej — w formie bardziej literackiej — Andrzej Falkiewicz ${ }^{3}$. Zdaniem Taylora jednostka uwikłana jest w sieci znaczeń, które są przez nią zastane i do których nie może się nie odnieść, jej tożsamość, generowana przez wyznawane wartości ${ }^{4}$, w dużej mierze tworzona jest więc społecznie.

Odpowiedzią na pytanie o możliwość bycia ,,autentycznym" może też być szersza refleksja nad c e r e m o n i a ł e m rozumianym jako ogół konwencjalnych zachowań wymuszanych na nas przez kulturę. Taką refleksję podjęli między innymi: Helmuth Plessner — podkreślający, jako jeden z pierwszych, rolę dyplomatycznego społeczeństwa, umożliwiającego, w przeciwieństwie do wspólnoty, relację pomiędzy potencjalnie nieskończoną liczbą ludzi o różnych celach — i Andrzej Falkiewicz, szeroko opisujący rolę zbiorowości w kształtowaniu jednostek ludzkich, ich postaw i zachowań. Efektem rozważań Falkiewicza była koncepcja człowieka teatralnego, wpisana w szerszą ideę istnienia-jako-metafory ${ }^{5}$.

Pytanie filozoficzne, które stoi za przeciwstawieniem autentyczności i ceremoniału (czy tė̇ teatralności) brzmi następująco: czy istnieje, a jeśli tak to jaki, zakres wolności w kształtowaniu tożsamości na gruncie modelu opisującego świat jako międzyludzki teatr, a jednostki jako aktorów respektujących społeczne wartości? Taylor zauważa, że te społeczne wzorce są tak silne, że jedynie niezwykle potężny charakter mógłby być na tyle wolny od nacisków opinii innych ludzi, by stanąć w prawdzie o sobie, jakakolwiek by nie była ${ }^{6}$.

Reasumując, aby odpowiedzieć, czy możemy tożsamość skonstruować choć po części niezależnie od narzucanych norm - a zakładamy na potrzeby tych rozważań ich prymarną rolę w konstruowaniu naszych self - sięgniemy do prac filozoficznych Falkiewicza, zestawiając je z krytyką radykalizmu przedstawianą przez Plessnera, a silnie powiązaną z zagadnieniem ceremoniału. Jak wspomnieliśmy, Plessner wskazuje na nieuchronność noszenia masek i konieczność istnienia ceremonialnego społeczeństwa przeciwstawnego naturze. Takie spojrzenie, ko-

\footnotetext{
${ }^{2}$ Zob. Ch. Taylor, Etyka autentyczności, tłum. A. Pawelec, Warszawa 1996.

${ }^{3}$ A. Falkiewicz, Teatr Społeczeństwo, zob. szczególnie s. 203-204. W książce tej Falkiewicz wieszczy konieczną, ostateczną śmierć systemu filozoficznego (obecnego implicite w nowożytnym paradygmacie myślenia) opartego na wierze, że prawdziwe jest to, co autentyczne, pochodzące z wnętrza podmiotu, a nigdy to, co przychodzi do niego ,z zewnątrz", to jest, że pojedyncze życie jest prawdą, którą trzeba wyzwolić od fałszu narzuconego przez zbiorowość. Do wniosku tego dochodzi, analizując rewolucyjną, jego zdaniem, zawartość dramatów Jeana Geneta i Witolda Gombrowicza, zwracających uwagę na wydatną rolę tego, co „,sztuczne”, ceremonialne, międzyludzkie i narzucone w czynieniu nas ludźmi.

${ }^{4}$ Ch. Taylor, Źródła podmiotowości - narodziny tożsamości nowoczesnej, tłum. M. Gruszczyński et al., Warszawa 2001, s. 135: „orientacja względem dobra nie jest jakimś wnoszonym przez nas z zewnątrz do świata dodatkiem, wiążącym się z wyborem opcji, w którą to sprawę można się zgodnie z wolą zaangażować lub nie, lecz [...] jest raczej warunkiem naszej tożsamości podmiotowej."

5 Zob. A. Falkiewicz, Istnienie i metafora, Wrocław 1994.

${ }^{6}$ Ch. Taylor, Źródła podmiotowości, s. 64.
} 
rzystające także z terminologii wypracowanej przez Taylora, umożliwi ujrzenie propozycji Falkiewicza w szerszym kontekście problemowym i umieszczenie ich w tradycji zachodniej antropologii filozoficznej, jak również postawienie prowizorycznej odpowiedzi na pytanie o wolność człowieka w świecie modelowanym podług teorii uznającej: 1. koncepcje dobra i zestawienie ich w konkretnej hierarchii za konstrukt społeczny, a co za tym idzie 2. społeczny (temporalno-historyczny) charakter tego, co nazywamy ludzką tożsamością (unikalna ludzka podmiotowość realizowana w wolnych czynach i decyzjach).

Najpierw przedstawimy Falkiewiczowskie rozumienie ceremoniału, następnie przedstawimy koncepcję homo theatralis i istnienia-jako-metafora, później zrekonstruujemy najważniejsze koncepcje Helmutha Plessnera, na końcu wyprowadzimy wnioski i odpowiemy na przedstawiony problem.

\section{Forma, ceremoniał, inscenizacja społeczna}

Falkiewicz o roli ceremoniału po raz pierwszy pisze w książce Teatr Społeczeństwo, w której dochodzi do wniosku, że to, co nazywamy prawdą, zawsze przychodzi do człowieka ,z zewnątrz"; prawda ta ma charakter społeczny, jest wzorcem i ,symbolem scalenia" w ogólnoludzki byt, daje znaczenie i sens, konstruuje człowieczeństwo ${ }^{7}$. Natomiast w dziele Polski kosmos: dziesięć esejów przy Gombrowiczu $u^{8}$ zwraca uwage na obecne w literaturze Witolda Gombrowicza pojęcie Formy i pragnąc je dookreślić, utożsamia je z ceremoniałem właśnie, który oprócz sensów, które przekazuje w postaci kulturowego kodu, ma także ,jeszcze to pierwsze i podstawowe znaczenie, że jest atrybutem człowieczeństwa"9. Bycie człowiekiem może się odbywać tylko za jego pośrednictwem, który w kolejnych tekstach Falkiewicz nazywać będzie również inscenizacją społeczną ${ }^{10}$. Podstawową rolą inscenizacji społecznej jest dla Falkiewicza czynienie nas ludźmi i tym samym, jak pisze filozof, powstrzymywanie przed patrzeniem w Próżnię ${ }^{11}$. Owa Próżnia dla Gombrowicza była tym, czego uświadomienie sobie istnienia doprowadza w człowieku do poczucia bezwartościowości systemów teoretycznych; tym, co budzi trwogę wobec kosmicznego ogromu i konieczności śmierci'12. Można ją, naszym zdaniem, próbować dookreślić za pomocą kategorii heideggerowskich. Martin

${ }^{7}$ A. Falkiewicz, Teatr Społeczeństwo, s. 69: ,,Prawda ludzka nie bije od wnętrza, przybywa zawsze do adepta z zewnątrz. Jest ona tym, co ludzi łączy, a łączyć może jedynie pod warunkiem, że będzie zrozumiała, powszechniej zrozumiała niż język słów [...] Te warunki spełnia zmaterializowany, odciśnięty w materii ceremoniał."

${ }^{8}$ A. Falkiewicz, Polski kosmos — dziesięć esejów przy Gombrowiczu, Kraków 1981.

${ }^{9}$ Ibidem, s. 121.

${ }^{10}$ Pojęcie „ceremoniału” doprecyzowuje w Istnieniu i metaforze z roku 1996. Utożsamia je tam z ,inscenizacją społeczną”. W jego ujęciu istnieje więc relacja tożsamościowa: Gombrowiczowska Forma $=$ ceremoniał $=$ inscenizacja społeczna.

11 A. Falkiewicz, Polski kosmos..., s. 121.

12 Zob. W. Gombrowicz, Kosmos, Kraków 1986. Spostrzeżenie, że ludzka Forma jest u Gombrowicza konstruowana przeciwko chaosowi przyrody (względnie: przeciw kosmosowi, przeciw próżni, przeciw śmierci...) i stąd u pisarza figura człowieka jako małpy, wyczyniającej ,,grymasy" wobec pustki, zawdzięczam prof. Dariuszowi Dobrzańskiemu. 
Heidegger pisał o prześwicie prawdy o pierwotnym rzuceniu, gdy Dasein wyrwane z codziennego obchodu orientuje się, że nie wie kim jest, skąd przychodzi i dokąd zmierza. Być może przed taką trwogą zabezpieczać ma wszechwładna Gombrowiczowska Forma, rozumiana po Falkiewiczowsku jako ceremoniał, czyli ogół rytualno-konwenansowych, wysoce skonwencjalizowanych zachowań społecznych ustrukturyzowanych nakazami i zakazami. Podobnie rzecz widzi Plessner — którego będziemy analizować później — jednak nie pisze on o Próżni, a o ,,rozpaczy swojego wnętrza", z której przejść musimy do społeczeństwa, w którym staje się możliwe samopotwierdzenie ${ }^{13}$.

Przeciwko pustce konstruujemy Formę, powiada Falkiewicz i przywołuje słynny cytat z Dzienników 1957-1961 Gombrowicza: „Być człowiekiem to znaczy być aktorem — być człowiekiem to znaczy » zachowywać się« jak człowiek, nie będąc nim w samej głębi — być człowiekiem to recytować człowieczeństwo"14.

Ten cytat to punkt wyjścia do dalszych rozważań Falkiewicza nad genezą i rolą ceremoniału, które wiążą się z ukuciem koncepcji „człowieka teatralnego”. Znajdziemy je w dziele pod tytułem Istnienie $i$ metafora.

\section{Falkiewiczowska koncepcja ,człowieka teatralnego"}

Falkiewicz pisze we wstępie tej pracy, że „szczątki kostiumów i rytuałów” upewniają nas w przekonaniu, że inscenizacja obecna jest w życiu zbiorowym człowieka od dawna, a główną jej rolą jest uczynienie nas ,pełnoprawnym członkiem zbiorowości, czyli człowiekiem"15. Jest to podstawowe założenie koncepcji homo theatralis (to samo znajdujemy u wcześniejszego Plessnera i późniejszego Taylora). Zdaniem poznańskiego filozofa „teatralność” człowieka polega na tym, że jego zachowanie zawsze jest częściowo n i e s z c z e r e — czyli niezgodne z prywatnymi uczuciami i odczuciami. Ta teatralność, sztuczność bycia człowieka w przestrzeni publicznej umożliwia współżycie z innymi. Podobnie pisał o ceremoniale Plessner, że jego ,atmosferą jest uprzejmość”, a „obraźliw[ą] obojętność, zimno i obcesowość wzajemnego mijania się w pośpiechu neutralizują f o r m y [wyróżnienie - I.G.] uprzejmości, szacunku i grzeczności, nazbyt wielkiemu zbliżeniu przeciwdziała rezerwa" ${ }^{\text {. }}$

Społeczny teatr, w którym porusza się homo theatralis, charakteryzują wedle Falkiewicza trzy główne predykaty: materialność, symbolowość, kłamliwość ${ }^{17}$.

Co oznacza materialność teatru? Genealogicznie wcześniej, zdaniem autora Istnienia i metafory, społeczny teatr jest materialny, ponieważ posługiwał się u początku swych dziejów oswojonym przedmiotem, czyli fetyszem, który jest archetypem symbolu. W tym zakresie Falkiewicz powołuje się na badania Jeana Piageta,

${ }^{13}$ H. Plessner, Granice wspólnoty - krytyka radykalizmu społecznego, tłum. J. Fischer, Warszawa 2008, s. 114.

${ }^{14}$ Cyt. za: A. Falkiewicz, Polski kosmos..., s. 123.

15 A. Falkiewicz, Istnienie i metafora, s. 22.

16 H. Plessner, Granice wspólnoty..., s. 99.

17 O sztuczności ceremoniału pisze także Plessner, podkreślając zarazem jego konieczność. Zob. ibidem, s. 116-117: ,Analiza podstawowych postaw cywilizacyjnych, ceremoniału i prestiżu, oprócz ich głębokiej konieczności ukazuje dobitnie ich sztuczność, którą się człowiek otacza [sic!]”. 
który wykazuje, że ,zarówno myślenie, jak i mowa dziecka mają podstawę empiryczną [ponieważ] są uogólnieniem operacji dokonywanych na rzeczach"18. Wyróżniony przedmiot, który staje się fetyszem „bezgłośnie przemawia” - nie wiadomo, co przekazuje, co sugeruje, przed czym jest ostrzeżeniem. Jego tajemniczość polega na „niedookreśloności”. W przeciwieństwie do symbolu, który jak zauważa Paul Ricoeur, odsyła do konkretnych elementów językowych, lecz także trudniejszych do uchwycenia elementów niejęzykowych ${ }^{19}$, fetysz nie odsyła do żadnych konkretnych sensów. Być może odniesienie do sfery sacrum istnieje również w przypadku fetyszu, różnica polega jednak na tym, że to, na co nas nakierowuje jest wysoce niejasne. Jest zagadką: ani pytaniem, ani odpowiedzią - może niemym wołaniem, reakcją na niewiedzę człowieka o swoim miejscu we wszechświecie? Falkiewicz dookreśla fetysz jako „materialny przedmiot oswojony przez człowieka” i dopatruje się w nim śladów „oddzielenia pierwiastka ciała ludzkiego od materii świata”20, czyli momentu w historii człowieka, kiedy zauważył nieprzekraczalną odrębność świata od siebie, na przykład kamienia od swojego ciała. Dlatego być może najważniejszą i najciekawszą dla człowieka cechą oswojonego przedmiotu wykorzystanego jako fetysz jest to, ż e n i e jest m n ą.

W drugim punkcie dla Falkiewicza teatr jest symbolowy. Omówiłem już symbol, wskazując na różnice między nim a fetyszem. Dodam, że Hans-Georg Gadamer oraz Mircea Eliade zauważali, że ważną rolą symbolu jest odsyłanie do sfery sacrum ${ }^{21}$. Przykładem realizowania ceremoniału jest obrządek religijny, który wprost odsyła do sacrum i jednocześnie jest materialny, posługuje się symbolami i językiem.

W trzecim punkcie teatr jest kłamliwy — to znaczy, nie jest zobligowany do mówienia prawdy ${ }^{22}$ (prawda jest tutaj rozumiana po Arystotelesowsku). W ten sposób pojawia się — oprócz konieczności życia i śmierci — „c z y s t a mo ż n o ść," jak to ujmuje Falkiewicz ${ }^{23}$. Już pomyślane, już wypowiedziane staje się pewną (społeczną) prawdą (już nie w rozumieniu Arystotelesowskim). Światem człowieka zaczyna rządzić d ow ol ość — odbywająca się poprzez język, czyli system symboliczny ${ }^{24}$ — która jest odpowiedzią na Gombrowiczowską próżnię konieczności śmierci, wobec której małpa wyczynia swoje grymasy' oto ,,drażnienie się nasze, gdzieś w galaktyce, ludzka prowokacja w ciemnościach, dokonywanie dziwacznych ruchów w otchłani”'25.

\footnotetext{
18 A. Falkiewicz, Istnienie $i$ metafora, s. 32.

19 P. Ricoeur, Język, tekst, interpretacja, tłum. P. Graff, K. Rossner, Warszawa 1989, s. 135.

${ }^{20}$ A. Falkiewicz, Istnienie i metafora, s. 33-34.

${ }^{21}$ H.-G. Gadamer, Prawda i metoda, tłum. B. Baran, Warszawa 2004, s. 121; M. Eliade, Sacrum i profanum, tłum. R. Reszke, Warszawa 1999, s. 8.

${ }^{22}$ A. Falkiewicz, Istnienie $i$ metafora, s. 37: ,kłamliwy — to znaczy nie skazany na mówienie prawdy", ,myśl, oderwana od treści ukształtowanego w nas genetycznie doświadczenia, odrywa się od świata [...]. Odtąd możliwe są dowolnie tworzone fabuły [...] Tak pojawia się językowy eksperyment, językowy żart, kłamstwo i grafomania."

${ }^{23}$ Ibidem.

${ }^{24}$ Ibidem, s. 40. Z kolei warunkiem zaistnienia systemu symbolicznego jest ceremoniał, który jest „,niezbywalnym kontekstem każdej wypowiedzi."

${ }^{25}$ Cyt. z Pornografii W. Gombrowicza za: A. Falkiewicz, Polski kosmos..., s. 122.
} 
Inscenizacja społeczna oddziela więc ,,sposoby zachowań od procesów fizjologicznych" i wywyższa człowieczeństwo nad jej biologicznych nosicieli ${ }^{26}$, jest tym, co nas wszystkich, niejako ponad nami, z sobą wiąże.

\section{Człowiek teatralny jako modus istnienia-jako-metafora}

Jak podkreśla Falkiewicz, istnieć to znaczy wykraczać poza własną fizyczność, czyli bytować ponad (meta) fizycznie, to jest - metaforycznie ${ }^{27}$ i nie chodzi tutaj o grę słów, lecz o przysparzanie byciu istnienia poprzez wykraczanie poza siebie. W ten sposób filozof definiuje byt jako „stawanie się”, „pragnienie bytu skierowane na zewnątrz" ${ }^{28}$. Istnienie zawsze dzieje się na pograniczu ja i nie-ja, poznane-nieznane, oswojone-nieoswojone - celem jest więc to, aby swój byt nieustannie pomnażać i przekraczać ${ }^{29}$ :

Jestem »tu«, ale jeżeli chcę utrzymać się w świecie, muszę się zarazem znaleźć

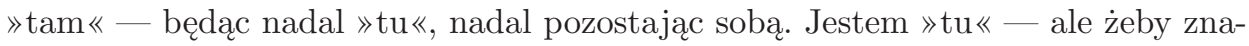
leźć się »tam«, muszę je wpierw oswoić, określić według potrzeb własnej fizyczności. Tak powstaje metafora, na którą składają się dwa etapy: moje bycie »tu« i moje wybieganie $\mathrm{ku} »$ tam«. Metafora — zawierająca dwa składniki: to, czym oswajam, i to, co powinienem oswoić [...] określające i określane [...]. Istnieć to wykraczać poza własną fizyczność ${ }^{30}$.

Istnienie charakteryzuje dokonywanie aktów transcendencji. Jest to powinność bytu przekraczania siebie i włączania w byty obszerniejsze, ubogacając je $\mathrm{e}^{31}$. Heidegger pisał, że sens to bycie zrozumiałym. To możliwe jest tylko w obrębie zbiorowości, czyli zbioru większego od jednostki. Rolę przekraczania siebie, uczestniczenia w czymś obszerniejszym spełnia w odczuciu Falkiewicza inscenizacja społeczna, w której człowiek teatralny współtwarza spektakl, którego finał jest nieznany; świat ludzki nie jest tutaj prostą sumą jednostkowych bytów ${ }^{32}$. Stanowisko to nazywamy holizmem.

Aby rozwinąć koncepcję człowieka teatralnego i uzyskać jej poszerzony obraz, porównajmy ją z badaniami Helmutha Plessnera nad radykalizmem.

\footnotetext{
26 A. Falkiewicz, Istnienie $i$ metafora, s. 41.

27 Ibidem, s. 390.

28 Ibidem, s. 391.

${ }^{29}$ Ibidem, s. 429.
}

30 A. Falkiewicz, Być może. Być - w stu trzydziestu czterech odsłonach, Gdańsk 2002, s. 35. W cytowanym zakresie powtórzenie tez z Istnienia $i$ metafory w skondensowanej formie.

31 A. Falkiewicz, Istnienie i metafora, s. 447-448.

32 Ibidem, s. 59-60: ,,[Ś]wiat ludzki jest oczywistą częścią świata pojmowanego niepomiernie szerzej, bytu branego w swym całokształcie. A przeto każda władza czy wiedza, w którą człowiek został wyposażony, jest ,zawdzięczana”: ma swe źródło w świecie pozaludzkim. Każde zaś odkrycie, jakiego za jej pomocą człowiek dokonać może, jest częścią świata, »głosem bytu «: czymś równie rzeczywistym, a więc nie-dobrowolnym, niezależnym od woli człowieka jak burza, piasek, czy rozgwieżdżone niebo. Jest mową świata." 


\section{Helmutha Plessnera koncepcja radykalizmu}

W książce Granice wspólnoty: krytyka radykalizmu społecznego Plessner podkreśla różnice dzielące wspólnotę (którą scala krew lub wspólna sprawa, a oddziela od reszty granica, za którą zostają inni przedstawiciele gatunku, lub indywidualna, radykalnie prywatna rzeczywistość życia ${ }^{33}$ ) od społeczeństwa (które zaczyna się tam, gdzie miłość i wspólnota krwi się kończą; jest ono w ujęciu Plessnera horyzontem, w którym możliwa jest relacja między potencjalnie nieskończoną liczbą ludzi $\left.^{34}\right)$. W dychotomii tak zdefiniowanej opowiada się Plessner za społeczeństwem, które umożliwia radzenie sobie z problemami i konfliktami, których nie można przekroczyć we wspólnocie (czy wspólnotach).

Plessner zauważa, że etos społeczeństwa charakteryzuje „tęsknota za maskami, które sprawiają, że bezpośredniość zanika", jednocześnie nadając życiom nowy sens, który „daje siłę do znoszenia tego, co przeciwne naturze”35. Istnieją tutaj więc wyszczególnione dwa momenty, które są istotne także w koncepcji homo theatralis - maski, które zakrywają pewną bezpośredniość i które w zamian projektują sens.

Człowiek w Plessnerowskiej koncepcji jest jednak jednocześnie „niezgłębiony”36, ponieważ u podstaw jego bytu jest, „wieczna potencjalność”37, ,zagadkowe źródło możliwości”38; człowiek jest „zarazem stawaniem się i bytem”39. Dostrzec można korespondencję pomiędzy Falkiewiczowską koncepcją istnienia-jako-metafory, w której istnienie dzieje się zawsze na pograniczu swojego ,,ja” i wybiegania ,kku”. Przypomnijmy, że w ujęciu poznańskiego filozofa swoistym modus tego bycia-jako-metafora jest teatralność istnienia, które włącza własne bycie w obręb zbiorowości, dając wrażenie istnienia w czymś obszerniejszym od „Ja”; mówiąc inaczej: rozszerza „Ja”.

Według Plessnera w obrębie zbiorowości jednostka nadaje sobie uogólnioną formę, czyli maskę, w której jest nietykalna wobec pozostałych członków zbiorowości, którzy — podobnie jak ona - muszą przestrzegać praw i form ceremoniału ${ }^{40}$. Pisze o tym między innymi w ten sposób: „Jednostka musi najpierw nadać sobie formę, w której jest nietykalna, swego rodzaju zbroję, w której udaje się na plac

${ }^{33}$ H. Plessner, Granice wspólnoty..., s. 50, 55-56, 62.

34 Ibidem, s. 65.

35 Ibidem, s. 45.

36 U Plessnera pod maskami jest więc istota ludzka, która jako „Ja” jest niepoznawalna nawet przez samą siebie. W odróżnieniu od znanej socjologicznej koncepcji Ervinga Goffmana, gdzie przybieranie maski wytwarza osobowość „prawdziwszą” niż to, co zaobserwować można w przestrzeni prywatnej. Zob. E. Goffman, Człowiek w teatrze życia codziennego, tłum. H. i P. Śpiewakowie, Warszawa 1981, np. s. 99: „nasz przemyślany charakter jest prawdziwszy nawet niż to, co niosą nasze niekontrolowane sny”. Co jest pod maską? „oblicze człowieka skupionego na swoim trudnym, zdradliwym zadaniu [inscenizacji — przyp. I.G.]". Dlaczego jest udręczony, skoro wytwarza osobowość ,prawdziwszą” niż poranna, zaspana twarz, oraz kto jest reżyserem — nie wiadomo.

${ }^{37}$ H. Plessner, Granice wspólnoty..., s. 71: ,,[... w rzeczywistości ludzie nigdy nie przenikają siebie do samego fundamentu, który zresztą nie jest określony, gdyż jest wieczną potencjalnością".

38 Ibidem, s. 77.

39 Ibidem, s. 75.

${ }^{40}$ Ibidem, s. 106: ,,Przestrzeganie jego praw i form [ceremoniału — przyp. I.G.] jest wiążące i nie potrzebuje żadnego racjonalizującego lub moralizującego uzasadnienia. Istnieje on po to, aby go przejąć i zastosować - przy cichej świadomości, że ma on charakter gry". 
boju, jakim jest sfera publiczna. [...] Wejście w sferę publiczną bez irrealnej kompensacji formy stanowi zbyt wielkie ryzyko" 41 .

Niemiecki filozof dodaje tutaj pojęcie prestiżu, który wzmacnia siłę oddziaływania w obrębie - mówiąc językiem Falkiewiczowskim — inscenizacji społecznej i który wynika z ,jednoznaczności, która emanuje z czynów i sprawia, że mamy wrażenie, iż wypływają one zawsze z żelaznej woli, co »w y m u s z a szacunek «"42.

Radykalizm, który jest przez Plessnera krytykowany, charakteryzuje natomiast między innymi zas a d niczość, czyli trzymanie się własnych zasad i przeświadczeń przy nieumiejętności korygowania ich; gotowość do ataku, która wynika nie z siły, lecz z obawy; także indywidualizm, który niesie przeświadczenie, że jednostka jest samowystarczalna. Radykalizm nie rozumie, zdaniem Plessnera, że

wieczna nieprzejrzystość konkretnych sytuacji, w której żyjemy od chwili naszych narodzin [...] zadaje kłam takiej ekstremistycznej postawie; w tym płynnym żywiole ręka nie uchwyci niczego, jeśli zamyka się w pięść. Ale nie uchwyci też niczego wówczas, gdy pozostaje całkowicie otwarta. Dlatego radykalizm, który afirmuje życie kosztem ducha i rozumu, przekształcając irracjonalno-dynamiczne żywioły w burzę, jest tak samo wrogi życiu i skazany na nieskuteczność, jak radykalizm racjonalistyczny ${ }^{43}$.

Radykalizm chce, żeby to własne, wewnętrzne zasady zawsze były siłami kształtującymi. Jest zaprzeczeniem cnót charakteryzujących ceremonialne społeczeństwo - zwłaszcza taktu ${ }^{44}$ rozumianego jako delikatność, naturalność i uprzejme dostrzeganie innych nawet przy bezwzględnym realizowaniu własnych celów. Według filozofa stan natury byłby nie do zniesienia, dopiero społeczeństwo daje możliwość bezbolesnego rozwiązywania konfliktów tak, że nie sprawiają one wrażenia, że są rozwiązywane wedle prawa silniejszego, wedle woli mocy. Ludzie muszą używać przemocy, ale musi być to osłodzone sztucznością i dystansem ${ }^{45}$.

Tu odnajdujemy różnicę między Plessnerem, który widzi ceremoniał teleologicznie głównie jako konieczny kostium, otoczkę i osłonę dla triumfów silniejszego wolą mocy, jako stwarzający dystans i umożliwiający godność nawet przegranemu, a Falkiewiczem, który ten sam ceremoniał widzi w swej funkcji głównie jako pomost, który pozwala spełniać się człowiekowi w wartościach i celach, które przekraczają długość osobniczego życia, innymi słowy, jako jeden z przejawów metaforycznego życia „na granicy”, „życia-ku” każdej jednostki. U podstaw, mówią zgodnie Falkiewicz i Plessner, mamy niezbadaną, niezgłębioną czystą potencjalność podmiotu.

${ }^{41}$ Ibidem, s. 101.

${ }^{42}$ Ibidem, s. 110.

${ }^{43}$ Ibidem, s. 9. Dodajmy, że zdaniem Plessnera zarówno irracjonalizm jak i racjonalizm chciałyby przenieść nieuświadamiane siły rządzące życiem do poziomu świadomości, by nad nim panować i dowolnie wzmacniać ich moc. Irracjonalista jest fanatykiem życia, racjonalista refleksji nad życiem — ale każde z tych ujęć oznacza ,unicestwienie zastanej rzeczywistości w imię idei". Syntetyzując, chodzi tutaj o wiarę, że można panować nad czynnikami życiotwórczymi; o wiarę w możliwość zrealizowania tego, czego się pragnie - a jest nieświadome - na w $ł$ a s n y c h, świadomych zasadach.

${ }^{44}$ Ibidem, s. 139: ,,radykalizm społeczny [jest] etyką braku taktu”"

${ }^{45}$ Ibidem, s. 167-168: „Czy ludzie, jeśli tylko naprawdę tego zechcą, nie mogliby żyć bez przemocy, bez sztuczności i dystansu, kierując się rozumem, miłością i szczerością? [...] Kosztowny eksperyment rewolucji zawsze odpowiadał negatywnie na to pytanie. Zawsze wychodziła na jaw nieusuwalność przemocy, nieuniknione związanie człowieka z prawami ostrożności, podstępu, nieprawdy [...]". 
Przejdziemy teraz do wniosków i spróbujemy odpowiedzieć na pytanie postawione we wstępie pracy: czy możliwa jest wolność w konstruowaniu tożsamości na gruncie modelu, w którym wartości konstruowane są na poziomie społecznym (więc metapoziomie dla uczestnika zbiorowości), a jeśli tak, to na jakich zasadach?

\section{Wnioski}

Ta wolność jest możliwa, ale w ograniczonym zakresie. Filozofia Falkiewicza dookreślona przez nas za pomocą aparatu terminologicznego Plessnera i Taylora - pokazuje raczej, że tożsamość podmiotu jest negocjowana, to znaczy, że stanowi wypadkową własnych pragnień i celów, które wypływają z tego, co Plessner nazywa „zagadkowym źródłem”, pewną czystą potencjalnością oraz ograniczeń, ram — „standardów", jak pisze Taylor, nakładanych na nas przez społeczeństwo. Realizowanie tej wolności leży dokładnie pomiędzy dosłownym realizowaniem społecznych norm i zakazów a negatywnym, krytykowanym przez Plessnera, radykalizmem pragnącym uczynić swoje zasady powszechnie panującymi. Szukać należy w tej szczelinie.

To znaczy, że chcąc być w maksymalnym stopniu sobą — w Taylorowskim sensie prawdy o sobie, odnajdywanej w radykalnie prywatnej przestrzeni — może się okazać, że chcemy realizować wartości inne od tych realizowanych aktualnie poprzez społeczeństwo. Falkiewicz zauważa, że dla zbiorowości ludzkiej ,,ważny jest stopień nowości, twórczy wkład, który każdy jego członek wnosi do wspólnej puli"46. To po pierwsze, wskazuje na to, że zbiorowość nie może być jedynym źródłem wartości, a po drugie, że próba zrealizowania tego ,twórczego wkładu” wiąże się z ryzykiem. Wkład jest wkładem o tyle, o ile wykracza poza to, co już obecne w kulturze. Mówiąc potocznie jest tym, co aktualnie ,nie mieści się w głowach” poszczególnych uczestników ceremoniału, przyjmujących zastaną rzeczywistość moralną za oczywistość. Reakcją może być odrzucenie, niekoniecznie włączenie indywidualnie wyznawanych wartości, w jakiś sposób uzewnętrznianych czy propagowanych, w obręb tych wyznawanych kolektywnie ${ }^{47}$. Im większe odstępstwo moich celów od celów społeczeństwa, tym większe ryzyko i większa stawka. Jeżeli pokrywają się z celami społeczeństwa, jestem idealnym obywatelem i współplemieńcem, jednocześnie będąc najmniej wartościowy, ponieważ nic nowego nie wnoszę, nie mogąc się przyczynić do zmiany paradygmatu czy korekty standardów. Przykładem sprzeciwu wobec historycznej wspólnoty przywoływanym przez Taylora jest Sokrates ${ }^{48}$. Zaprzeczył on swojej egoistycznej woli życia (możliwość ucieczki), by zrealizować normy wyznaczane przez ateńską wspólnotę i dobrowolnie przyjęte przez jej członków. Inny przykład to Antygona, która pogrzebała brata, sprzeciwiając się normom społecznym, określonym przez historycznie uformowaną wspólnotę, przyznając się tym samym do wartości postrzega-

46 A. Falkiewicz, Teatr Społeczeństwo, s. 34.

${ }^{47}$ Mechanizm pojawiania się w kulturze nowych wartości, wprowadzanych do świata duchowego przez ,,proroków" i warunki ich asymilacji — na przykładzie procesu rozwoju i upadku religii — modelował za pomocą metody idealizacji Leszek Nowak na gruncie nie-Marksowskiego materializmu historycznego. Zob. P. Buczkowski, A. Klawiter, L. Nowak, Religia jako struktura klasowa, [w:] U podstaw teorii teorii socjalizmu, t. I. Własność i władza, L. Nowak (red.), Poznań 1991, s. 271-313.

${ }^{48}$ Ch. Taylor, Źródła podmiotowości..., s. 73. 
nych (obecnie) jako bardziej uniwersalne (chęć godnego pochówku członka rodziny). Sprzeciw wobec historycznie rozumianej wspólnoty, w obu przypadkach, odbył się nie na kanwie krytykowanego przez Plessnera radykalizmu, który jest zamknięciem, odcięciem, lecz na kanwie Falkiewiczowskiego metaforyzowania, przekraczania siebie, utożsamienia się z większą zbiorowością lub bardziej uniwersalnymi ideałami. Falkiewicz pisze, że ,,administracja staje się tym odporniejsza, im gwałtowniej się przeciw niej występuje"49. Jednak przykłady losów takich historycznych postaci jak Jezus Nazarejczyk, czy wspomniana Antygona świadczą o tym, że zgładzenie przeciwnika wnoszącego do kultury nowe, rewolucyjne wartości, nie musi doprowadzić do tryumfu moralności, w myśl której owych konkurentów się pozbyto, a wręcz przeciwnie. Częstokroć obnaża to słabość systemu wobec tych, których ,prawdy” zostaną wkrótce uznane za ,prawdziwsze” (w tym sensie, że stają się masowo wyznawane - czasem za cenę śmierci wyznawców, ale dzięki temu odnoszą tryumf, który trwa aż do czasu pojawienia się nowych, rewolucyjnych wartości $\left.{ }^{50}\right)$.

To oznacza, że pewien zakres wolności istnieje: wybór jest realny, ale zapewne dany nielicznym. Pojawia się pytanie, jakie jest źródło tych nowych wartości gdzie są one odnajdywane i opracowywane? Plessner w tym miejscu zatrzymuje się, umieszczając aksjomat o ,niezgłębialności ludzkiego wnętrza”. W rozważaniach Leszka Nowaka na temat struktury rewolucji religijnych zakłada się, że procesu pojawiania się proroków, którzy wnoszą do kultury nowe wartości, nie da się poddać modelowaniu i należy w tym zakresie założyć losowość. Można na gruncie jego nie-Marksowskiego materializmu historycznego próbować przewidzieć, w jakim momencie historycznym się znajdujemy — czy takim, który sprzyja powstaniu nowej religii lub światopoglądu, czy też takim, w którym obowiązujący „,paradygmat” (system duchowy) jest na tyle silny, że jest w stanie wchłonąć nowe „,proroctwa” (czyli odkryte właśnie, nieznane wcześniej, koncepcje dobra). Ale sam proces ich odkrywania również tutaj owiany jest tajemnicą. W każdym razie ów brak determinizmu i pewien zakres wolności w ,odkrywaniu" nowych koncepcji dobra nie oznacza, że jednostka poprzez swój wyrażony wszem i wobec sprzeciw wobec społecznych źródeł moralności może przestać funkcjonować w inscenizacji społecznej, że nie jest już, mówiąc znów po Taylorowsku, w konwersacji z innymi. Należy raczej założyć, że podmiot zawsze i wszędzie musi funkcjonować w sieci, w której będzie zrozumiały i musi zderzać się z innymi podmiotami i wartościami.

W tym ujęciu poświęcenie życia bytowi obszerniejszemu ode mnie, z którym się utożsamiam (rodzinie, plemieniu, narodowi) dlatego bywa częstokroć hołubione, ponieważ jest — jak zauważa Falkiewicz — racjonalne ${ }^{51}$, racjonalne w chwili, w której na tę racjonalność zdobyłoby się niewielu. Oddanie życia za ludzkość przez Jezusa Nazarejczyka byłoby konsekwentnym ruchem wynikającym z przyznania się do największej podówczas możliwej zbiorowości, wbrew ówczesnym społecznym standardom o innej perspektywie. Plessnerowsko krytykowany radykalizm byłby natomiast rodzajem niewoli ruchu wstecznego, zamknięciem się wy-

\footnotetext{
49 A. Falkiewicz, Teatr Społeczeństwo, s. 31.

50 To spostrzeżenie zawdzięczam cytowanemu artykułowi: Religia jako struktura klasowa.

51 A. Falkiewicz, Istnienie i metafora, s. 86-87.
} 
nikającym z dwojakich pragnień: po pierwsze, podniesienia do rangi świadomości wszystkich czynników życiotwórczych, które są nigdy możliwe do objęcia, a po drugie, uczynienia własnych zasad powszechnie panującymi. Ten radykalizm byłby zaprzeczeniem Falkiewiczowskiego paradygmatu istnienia-jako-metafora, której imperatyw każe scalać i utożsamiać się z obszerniejszymi od siebie bytami tak, by nieustannie siebie powiększać i przekraczać, a nawet ,,docierać do prawdy bytu" ${ }^{\prime \prime 2}$. Sugerujemy, że wartości konkurują z sobą, a wygrywają te, które obejmujac możliwie szeroki zakres bytów. Zauważmy, że dzisiaj mówi się już o konieczności przyznania praw niektórym bytom pozaludzkim, co świadczy o rozwoju ludzkiej moralności, od miłowania przyjaciół, przez miłowanie wrogów, aż do - a dlaczego nie? - objęcia prawami (czyli miłością?) wszystkich istnień, które uznajemy za czujące (vide: walka o prawa zwierząt).

Kolejnym pytaniem badawczym jest, jak już nadmieniliśmy, status tej prawdy (odnajdywanej wewnątrz ,Ja”, choć poprzez wybieganie „,ku”) i pytanie o możliwość jej uprawomocnienia. To jednak temat na osobną rozprawę i na dalsze badania nad twórczością Andrzeja Falkiewicza i zagadnieniami filozoficznymi przez niego poruszanymi.

\section{Bibliografia}

Buczkowski P., Klawiter A., Nowak L., Religia jako struktura klasowa, [w:] L. Nowak, U podstaw teorii socjalizmu, t. 1: Własność i władza, Poznań 1991, s. 271-313.

Eliade M., Sacrum $i$ profanum: wykłady o istocie religijności, tłum. R. Reszke, Kraków 1999.

Falkiewicz A., Być może: być - w stu trzydziestu czterech odsłonach, Gdańsk 2002

Falkiewicz A., Fragmenty o polskiej literaturze, Warszawa 1982.

Falkiewicz A., Istnienie i metafora, Wrocław 1996.

Falkiewicz A., Polski kosmos: dziesięć esejów przy Gombrowiczu, Kraków 1981.

Falkiewicz A., Teatr Społeczeństwo, Wrocław 1980.

Gadamer H.-G., Prawda i metoda, tłum. B. Baran, Warszawa 2004.

Goffman E., Człowiek w teatrze życia codziennego, tłum. H. i P. Śpiewakowie, Warszawa 1981.

Gombrowicz W., Dziennik 1953-1969, Kraków 2013.

Plessner H., Granice wspólnoty: krytyka radykalizmu społecznego, tłum. J. Fischer, Warszawa 2008.

Ricoeur P., Język, tekst, interpretacja, tłum. P. Graff, K. Rossner, Warszawa 1989.

Taylor Ch., Źródła podmiotowości - narodziny tożsamości nowoczesnej, tłum. M. Gruszczyński et al., Warszawa 2001.

${ }^{52}$ Ibidem, s. 60. 